Інноватика у вихованні. Випуск 12. 2020.

У ДК 371(410)(043,3)

DOI: $10.35619 /$ iiu.v1i12.324

\author{
Iryna Budz \\ Candidate of Pedagogic Sciences, \\ Associate Professor at the Department \\ of Romano-Germanic Philology, \\ Academician Stepan Demianchuk \\ International University of Economics and Humanities, \\ Rivne, Ukraine \\ ORCID: 0000-0003-1127-3568 \\ e-mail:ibudz@ukr.net
}

\title{
PROSPECTS OF THE USE OF GREAT BRITAIN'S EXPERIENCE IN THE EDUCATIONAL SYSTEM OF GIFTED SCHOOLCHILDREN IN UKRAINE
}

\begin{abstract}
The article researches the state of education of gifted schoolchildren in Ukraine. The analysis of the domestic education system for gifted children has revealed that despite some achievements in this area, Ukraine needs to improve mechanisms that will eliminate shortcomings in educating gifted children and promote the organization of effective education and upbringing of schoolchildren of this category.

It has been found out that at the level of the legislative component, the public interest in the problem of gifted pupils is presented in a number of laws and regulations, and it is recommended to develop and implement a cross-cutting National Curriculum for gifted schoolchildren and quality standards for education that provide effective measures for gifted pupils and students at the local, regional and national levels.

The main directions of gifted education in Ukraine at the level of organizational and institutional component have been defined and recommendations are provided for the purpose of systematic maintenance in teachers' training for work with gifted pupils.

The communicative component of the domestic education system for gifted schoolchildren is primarily represented by the media, which reflect current issues in the field of theory and practice of gifted development. At the level of the communicative component, the following is proposed: creation of a network of specialized periodicals and development of online resources.

Key words: gifted schoolchildren, education of gifted and talented pupils, legislative component, organizational and institutional component, communicative component, recommendations.
\end{abstract}

Problem statement. The way of the problem solving of the potential talent realization of each individual, the optimal development of human abilities, identifying and supporting talented children and youth is recognized as one of the priority tasks of modern pedagogical science. The modern school is faced with the task of maximum disclosure and development of the potential of each individual, the formation of a man as a subject of social and professional life, preparing him for self-improvement, selfdetermination and self-realization. The modern Ukrainian school must ensure the 
comprehensive development of the individual as the highest value of society on the basis of identifying his talents, abilities, and gifts. That is why, Ukraine has adopted a number of laws and programs that aim at creation of a national network of educational institutions for gifted youth. However, this is only the beginning of a long and hard work of the whole society on the way to the realization of the set tasks.

Research publications analysis. Researchers, teachers-practitioners analyze, create, improve methods of work with gifted and talented pupils, study the activities of educational organizations, research the content of teaching gifted, make and implement program documents, work on improving innovative methods. Directions of education reform in Ukraine, aspects of the essence of the nature of giftedness, theoretical and methodological principles of teaching, educational work with gifted children were considered in scientific research of Ukrainian scientists, namely O. Antonova, A. Bida, O. Kulchytska, L. Lypova, R. Naumenko, S. Terepyshchy, L. Prokopiv, J. Rudyk, L. Slobodyniuk, V. Strelnikov, M. Fedorov and others.

The aim of the article is to provide recommendations for the implementation of the positive experience of Great Britain in educating gifted schoolchildren in the domestic educational practice at the level of legislative, organizational and institutional, communicative components.

Presenting the main research material. The experience of Great Britain as the most successful in the field of science and education and highly developed country can be useful in the process of creating favorable learning conditions for gifted schoolchildren who could fully reveal and develop their natural talents (Kholod, 2015, p.119).

Taking into account the drawbacks in the domestic practice of gifted children education (Budz, 2016), practical recommendations have been developed for the implementation of the British experience in Ukrainian educational practice at the legislative, organization and institutional, communicative levels.

The previous analysis shows that the legislative component of the education of gifted children in Ukraine is represented by a number of normative documents that aim at solution of strategic tasks (Budz, 2016). However, educational practice, taking into account the requirements of the time, needs to improve the legal and regulatory framework, which would contribute to the successful development of creative and intellectual potential of the youth of Ukraine.

In this regard, the experience of Great Britain is noteworthy, the multilevel structure of primary and secondary education which allows to identify gifted and talented students gradually, group them according to the provisions of the England's National Program for Gifted and Talented Education (2016), to develop their abilities at each stage, to provide equal opportunities and resources regardless of social status, place of residence, ethnicity and gender.

In Ukraine the National Program for gifted schoolchildren should be cross-cutting: cover all educational stages and be implemented at different levels (local, regional and national).

The development of specific quality standards for education which provide effective measures for gifted pupils and students at classroom, extra classroom, local, regional and national levels is urgent as well.

At the level of organizational and institutional component of education of gifted children in Ukraine, the following shortcomings have been identified: lack of continuity, interdependence and systematization in the activities of government agencies in work with gifted children (public sector); activities of a critically small 
number of charitable organizations in the field of gifted development (nongovernmental sector) (Budz, 2016).

In this regard, the necessity to create a special unit of the Ministry of Education and Science of Ukraine at the public sector that would work with gifted children on the model of the Department of Education and Training, the UK, has occurred. One of the important tasks of this structure is to solve the problem of identifying gifted children by implementing the following:

coordination of the activities of all institutions that make up the infrastructure in education of gifted children;

exclude the directive nature of methods of identification of gifted children (taking into account age and peculiarities of educational subjects);

granting autonomy to schools in the process of identifying the gifted and talented schoolchildren, taking into account quantitative and qualitative indicators, as well as the achievements of leading scientists and teachers-practitioners;

introduction of identification methods of this category children popular in the system of education for gifted in Great Britain: identification of gifted by subject teachers; questionnaires; testing; evaluation of children's creative works; nomination of gifted by their peers; information from parents; pupils' discussions; submission of employees of educational public organizations (sports coaches, teachers of local clubs, etc.).

In addition, the activities of the defined structure should be aimed at developing and implementing (along with existing ones) fundamentally new and high-quality programs for gifted children (such as London Gifted and Talented (2016) ) etc. The main purpose of the newly created programs is to provide educational support to gifted and talented schoolchildren through strategic approaches: to unite practitioners in societies; funding of local authorities that would be able to support the implementation of new school projects and curricula provided by the newly created structure at the Ministry of Education and Science of Ukraine; establishing business contacts with financially viable structures and the use of marketing companies; wide introduction of innovative technologies in educational practice.

All programs for gifted children must contain online resources, thus providing an opportunity to implement an individual approach to studying.

Curricula for gifted children provide a number of specific opportunities, namely: participation in seminars; constant provision of training courses; cooperation with peers, curators/mentors, division into groups; additional knowledge test; enriching the curriculum with additional resources; lectures by leading experts in certain fields; support courses for gifted children and training for all concerned; learning through online resources with the support of online tutors; online discussion forums.

Among the main requirements for the programs - an individual approach to every gifted and talented pupil (according to the age and needs), as well as individual selection of teachers and educators for them. Therefore, the main task of such programs is the simultaneous realization of the potential of talented and gifted children and the development of the potential of their teachers.

An important component of the system of selection of gifted and talented students is the proper training of teachers. As the analysis of the model of education for gifted and talented students in Great Britain has revealed, the teacher is given a leading place in the educational process in terms of the most effective classroom approach to meeting the educational needs of gifted and talented pupils (Budz, 2018). This approach is implemented through the direct interaction of the pupil and the teacher in 
the classroom, which requires teacher professionalism and obliges him to extraordinary responsibility.

Using the positive educational experience of Great Britain, we offer the following components of systematic teacher training to work with gifted children:

to improve existing and create new programs to support teachers (who work with certain categories of gifted) at the national, regional and local levels;

to improve training programs for future teachers by introducing professional disciplines into their content on the problem of giftedness and the introduction of special courses aimed at preparing to work with this category of children;

to create a system of support for gifted youth, which receives primarily pedagogical specialties (on the model of the National Academy for Gifted and Talented Youth (2005) ), the Open University, etc.;

in order to improve the qualification of teachers to work with gifted and talented schoolchildren to introduce offline and online training courses (modeled on the program of the Westminster Institute of Education at Oxford Brookes University (2005), Oxford University, created for gifted and talented coordinators);

creation of special online resources that would provide methodological support for teachers on the theory and methods of educating gifted children;

active participation of higher education institutions in the implementation of projects and educational programs for gifted and talented pupils.

It was found that at the local level school plays the main role in the development of gifted schoolchildren. In Great Britain school is central in the education model for gifted and talented pupils. In general, the school system is aimed at the development of each pupil. This is typical for many countries, including Ukraine. Therefore, taking the positive British experience into account, we offer:

a component of state social policy should be mandatory for each school to maintain a register of gifted and talented pupils, which should contain information about the socio-economic level of the pupil's family, gender and origin, which will meet the educational needs of gifted children from low-income families;

to optimize cooperation with parents of gifted schoolchildren and community representatives;

to improve the educational support of gifted schoolchildren through a curriculum that would combine classroom, school and extracurricular activities, which will increase the effectiveness of their education;

to introduce the position of coordinator for education of gifted and talented pupils, the main purpose of which is to work with teachers, parents, peers of potential gifted and talented and objective assessment of intellectual, creative as well as personal qualities of students in this category;

to increase attention to the development of giftedness in schoolchildren with special educational needs, etc.

The communicative component of the gifted education system in our country needs significant changes, as in Ukraine there are only a few periodicals that partially present the research problem. The only exception is the official website of the Institute of Gifted Children of the National Academy of Pedagogical Sciences of Ukraine, which provides methodological support for the education and upbringing of gifted children. Therefore, in order to improve the communicative component of the education system for gifted children in Ukraine, we offer:

to create a network of specialized periodicals for teachers-coordinators, for gifted children, as well as for their parents; 
to encourage researchers and teachers to cover the problems of education and upbringing of gifted children in the pages of general pedagogical newspapers and magazines;

to develop the Internet resources that would provide comprehensive information from school censuses on effective educational support for gifted and talented children in primary and secondary education, on the specification of identifying gifted and talented pupils, as well as on government education policy, etc.

Conclusion and further research prospects. The analysis of scientific and methodological support for the education of gifted students in Ukraine showed that, despite some achievements in this area, we need to improve mechanisms that would eliminate shortcomings in the domestic practice of education of gifted children and create an appropriate education system for schoolchildren in this category.

Taking into account the drawbacks identified in the domestic practice of education of gifted children, practical recommendations have been developed for the implementation of the British experience in domestic educational practice.

The proposed practical recommendations for the implementation of the British experience at the legislative, organizational and institutional, communicative levels will enrich the domestic theory and practice of education of gifted schoolchildren, which may be the basis for further research in this area. The analysis of domestic educational practice shows that in order to provide proper material and technical support for the education of gifted pupils at different levels (national, regional, local) in Ukraine, it is necessary to increase public funding of the organizational and institutional as well as communicative components of the gifted education system.

\section{СПИСОК ВИКОРИСТАНИХ ДЖЕРЕЛ}

Холод, І. (2015). Педагогічна підтримка обдарованої студентської молоді в університетах Великобританії. Кандидат педагогічних наук. Уманський державний педагогічний університет ім. Павла Тичини.

Будз, І. (2016) Організаційно-інституційна складова розвитку освіти обдарованих школярів в Україні. Психолого-педагогічні основи гуманізації навчально-виховного процесу в школі та ВНЗ. Вип. №2 (16). с. 21 - 28.

England's National Programme for Gifted and Talented Education (2016). URL: http://www.spanglefish.com/mariessite/Documents/.../906_world_conference.doc. [Дата звернення 15.10. 2020]

London Gifted and Talented. (2016) URL: http:// www.londongt.org._[Дата звернення 15.10. 2020]

Budz, I. (2018) Teacher's role in the process of identification and classroom approach of gifted and talented education in Great Britain. Інноватика у вихованні. Вип.8. с. $144-151$.

National Academy for Gifted and Talented Youth (2005). URL: http://www.warwick.ac.uk/gifted. [Дата звернення 10.10. 2020]
Oxford
Brooks
University
GIT
(2005).
URL:

http://www.brookes.ac.uk/schools/education/rescon/cpdgifted. [Дата звернення 10.10. 2020] 


\title{
REFERENCES
}

Kholod, I. (2015). Pedahohichna pidtrymka obdarovanoi studentskoi molodi $v$ universytetakh Velykobrytanii [Pedagogical Support for Gifted Student Youth at Universities of Great Britain]. Kandydat pedahohichnykh nauk. Umanskyi derzhavnyi pedahohichnyi universytet im. Pavla Tychyny. [in Ukrainian]

Budz, I. (2016) Orhanizatsiino-instytutsiina skladova rozvytku osvity obdarovanykh shkoliariv v Ukraini [Organizational and Institutional Component of the Development of Education of Gifted Schoolchildren in Ukraine]. Psykholohopedahohichni osnovy humanizatsii navchalno-vykhovnoho protsesu $v$ shkoli ta VNZ. Vyp. \#2 (16). s. 21 - 28. [in Ukrainian]

England's National Programme for Gifted and Talented Education (2016). URL: http://www.spanglefish.com/mariessite/Documents/../906_world_conference.doc. [Data zvernennia 15.10. 2020] [in English]

London Gifted and Talented. (2016) URL: http:// www.londongt.org._[Data zvernennia 15.10. 2020] [in English]

Budz, I. (2018) Teacher's role in the process of identification and classroom approach of gifted and talented education in Great Britain. Innovatyka u vykhovanni. Vyp.8. c. 144 - 151. [in English]

National Academy for Gifted and Talented Youth (2005). URL: http://www.warwick.ac.uk/gifted. [Data zvernennia 10.10. 2020] [in English]

Oxford Brooks University GIT (2005). URL: http://www.brookes.ac.uk/schools/education/rescon/cpdgifted. [Data zvernennia 10.10. 2020] [in English]

\section{ПЕРСПЕКТИВИ ВИКОРИСТАННЯ ДОСВІДУ ВЕЛИКОЇ БРИТАНІЇ В СИСТЕМІ ОСВІТИ ОБДАРОВАНИХ ШКОЛЯРІВ В УКРАЇНІ}

\author{
Ірина Будз \\ кандидат педагогічних наук, \\ доцент кафедри романо-германської філології \\ Міжнародного економіко-гуманітарного університету ім. акад. С. \\ Дем'янчука, \\ м. Рівне, Україна \\ ORCID: 0000-0003-1127-3568 \\ e-mail:ibudz@ukr.net
}

Анотація. У статті схарактеризовано стан освіти обдарованих школярів в Україні. Аналіз вітчизняної системи освіти для обдарованих дітей засвідчив, що незважаючи на певні досягнення в цій галузі, в Україні $\epsilon$ потреба удосконалити механізми, які призведуть до усунення недоліків у роботі з обдарованими дітьми та сприятимуть організації ефективного навчання й виховання дітей цієї категорії.

3'ясовано, що на рівні нормативного складника зацікавленість суспільства проблемою обдарованості дітей представлена в низці законодавчих та нормативних документів, та рекомендовано удосконалити законодавчонормативну базу з метою досягнення успіху в справі розвитку творчого та інтелектуального потенціалу молодого покоління України; розробити та впровадити наскрізну Національну програму навчання обдарованих школярів та 
стандарти якості освіти, які передбачають ефективні заходи для обдарованих учнів і студентів на місцевому, регіональному та національному рівнях.

Визначено основні напрями роботи з обдарованими дітьми в Україні на рівні організаційно-інституційного складника та запропоновано рекомендації з метою забезпечення системності в підготовці вчителів до роботи 3 обдарованими учнями.

Комунікативний складник вітчизняної системи освіти для обдарованих дітей передусім представлений засобами масової інформації, що відображають актуальні питання в галузі теорії та практики розвитку обдарованості. На рівні комунікативного складника запропоновано: створення мережі спеціалізованих періодичних видань (для учителів-координаторів роботи з обдарованими дітьми, для обдарованих дітей, для їхніх батьків); розвиток інтернет-ресурсів, які б надавали вичерпну інформацію шкільних переписів про ефективне навчальне забезпечення для обдарованих і талановитих дітей та їх ідентифікацію, а також інформували про політику уряду щодо освіти обдарованих i талановитих школярів.

Ключові слова: обдаровані школярі, освіта обдарованих і талановитих школярів, нормативний складник, організаційно-інституційний складник, комунікативний складник, рекомендації.

Стаття надійшла до редакиії 09.10. 2020 р. 